Mongolian Academy of Sciences
Mongolian Journal of Chemistry
Institute of Chemistry \& Chemical Technology

\title{
Characterisation of fly ashes from 4th Thermal Power Station of Ulaanbaatar city and its applicability for a zeolite synthesis
}

\author{
J.Temuujin A.Minjigmaa, B.Davaabal, Z.Ochirbat
}

Laboratory of Materials Science and Technology, Institute of Chemistry and Chemical Technology, Mongolian Academy of Sciences,

Ulaanbaatar 51, Mongolia

\begin{abstract}
Fly ash from 4th thermal power station of Ulaanbaatar city have been characterised by $\mathrm{x}$ ray fluorescence (XRF), x-ray diffractometry (XRD), particle size analyzer, specific surface area measurement (BET) and scanning electron microscope (SEM) observation. It was found that fly ash from Baganuur coal contains over $15 \mathrm{wt} \%$ of calcium oxide $(\mathrm{CaO})$ and could be assigned as class $\mathrm{C}$ fly ash, according to the International classification. Specific surface area of this fly ash was 2.75 $\mathrm{m}^{2} / \mathrm{g}$ and mean particle diameter was $59.5 \mu \mathrm{m}$. Zeolitic compounds were synthesised by using mixture of this fly ash and a transition aluminium oxide under hydrothermal treatment at 100, 150 and $200^{\circ} \mathrm{C}$ temperatures for a different duration. Various zeolitic compounds including Na-faujasite and sodium aluminosilicate were synthesised as reaction products.
\end{abstract}

Keywords: fly ash, characterisation, hydrothermal treatment, zeolite synthesis

\section{Introduction}

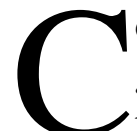
oal fired thermal power stations are generating a huge amount of byproducts such as fly ash and bottom ash. It was estimated that annual disposal of coal firing by-products is around 600 million tones worldwide with fly ash constituting about 500 million tones at $75-80 \%$ of the total ash produced [1]. Since, the coal firing byproducts are accumulating rapidly, it can be caused serious disposal problem. Most of the fly ashes are kept in an ash pond and disposed at landfill which could be considered as treat to land and water resources. Moreover, for the developed countries the disposal of the fly as will soon be too costly if not forbidden [2]. Coal firing by products have been used in construction related applications such as cement and concrete manufacturing, road and railroad bases, pavement, for the capture of industrial and water treatment wastes, sources of valuable metals, ceramic applications, synthesis of several type of zeolite etc. [3].

In Mongolia coal fired thermal power stations are producing over $90 \%$ of electricity. Especially in Ulaanbaatar city all the required electricity is producing by 3 thermal power stations and the largest one is 4th thermal power station. The 4th thermal power station is using Baganuur and Shivee-ovoo coals for firing and annual disposed coal firing by product is over 300.000 tones. However, in Mongolia utilisation rate of the coal firing by product is negligible and seems to be caused by a little knowledge of mineralogical and physical-chemical properties of the fly ash. The goal of the present research was characterisation of the Baganuur fly ash and elucidation of its applicability for a zeolite production. 


\section{Experimental}

Baganuur fly ash was used as raw material for the planned experiments. Chemical composition of the fly ash was determined by $\mathrm{X}$-ray fluorescence method (XRF, RigakuPrimini type), mineralogical composition by XRD (Brucker D8 Advance). Granulometry of the fly ash was determined by a laser diffraction particle size analyzer (ShimadzuSALD-2100). Specific surface areas of the fly ash and synthesised samples were determined by BET method at $-77 \mathrm{~K}$ (Belsorp mini). Samples were outgased at $200^{\circ} \mathrm{C}$ for $4 \mathrm{~h}$. High purity helium gas was used as adsorbate. Particle morphology was observed by SEM (JEOL-JSM-6701F). Powders were coated by carbon.

Zeolite syntheses were performed by using a Teflon lined hydrothermal bomb with volume of $20 \mathrm{~cm}^{3}$. As an additive $\mathrm{Al}$ component for the zeolite synthesis was use transition $\square$ $\mathrm{Al}_{2} \mathrm{O}_{3}$ for spectral analysis. The $\mathrm{Si}$ :Al ratio of the reaction mixture was $<1$. Addition of such high amount of $\mathrm{Al}$ was aimed to facilitate a low Si:Al ratio zeolite synthesis such as faujasite which reported as product of high industrial application [4]. Into the hydrothermal bomb were added 3 grams of fly ash $+\mathrm{Al}_{2} \mathrm{O}_{3}$ mixture and $20 \mathrm{ml}$ of the $\mathrm{NaOH}$ either 2 or $4 \mathrm{M}$ solutions. The zeolite crystallisation was studied after conversion at 100,150 and $200^{\circ} \mathrm{C}$ for $4,8,16$ and $24 \mathrm{~h}$. After the desired time, the hydrothermal bomb was removed from the oven and cooled down by water.

\section{Results and Discussion}

Chemical composition of the fly ash as follows wt.\%: $\mathrm{SiO}_{2}$ 53.05, $\mathrm{CaO} 15.5, \mathrm{Fe}_{2} \mathrm{O}_{3}$ 8.85, $\mathrm{MgO} 1.81, \mathrm{Al}_{2} \mathrm{O}_{3}$ 16.45, $\mathrm{K}_{2} \mathrm{O} 1.93, \mathrm{SO}_{3}$ 1.32, $\mathrm{K}_{2} \mathrm{O} 1.67, \mathrm{MnO} 0.175, \mathrm{TiO}_{2}$ 0.82. Based on the chemical composition it can be suggested that this fly ash belongs to class $\mathrm{C}$ fly ash according to the International classification. Fig.1 shows XRD pattern of the Baganuur fly ash. It contains quartz, anorthite and unassigned compound as crystalline compounds. Unlike to class F fly ash, the mullite diffraction peaks were not observed in Baganuur fly ash [5]. Probably coal firing temperature of the 4th thermal power station was not sufficient high to crystallise mullite from a clay impurity of Baganuur coal. Therefore, aluminum may exist within amorphous component and it may have a favourable effect for further processing of the fly ash. Fly ash consists of crystalline and amorphous components. However, because of methodological limitation, chemical composition of the amorphous component wasn't determined.

BET surface area of the fly ash was $2.75 \mathrm{~m}^{2} / \mathrm{g}$ and pore volume $0.000433 \mathrm{ml} / \mathrm{g}$. Particle size distribution (granulometry) analysis indicated that $25 \%$ of fly ash particles is less than 22.3 $\mu \mathrm{m}, 50 \%$ is less than $59.5 \mu \mathrm{m}$ and $75 \%$ is less than $106.7 \mu \mathrm{m}$, respectively.

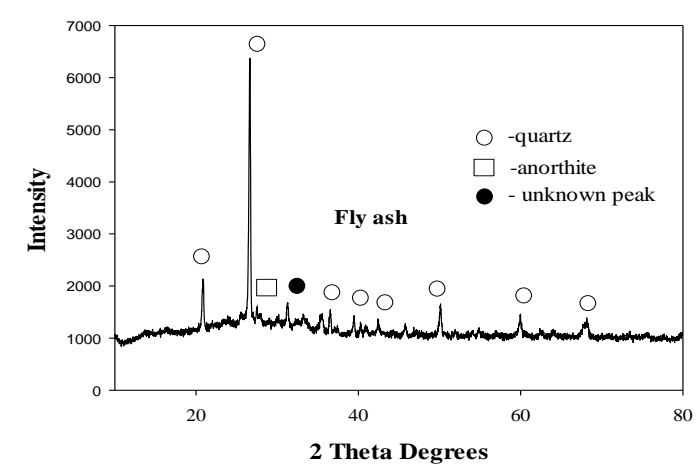

Fig.1 XRD pattern of the Baganuur fly ash.

Scanning electron microscope micrographs of the
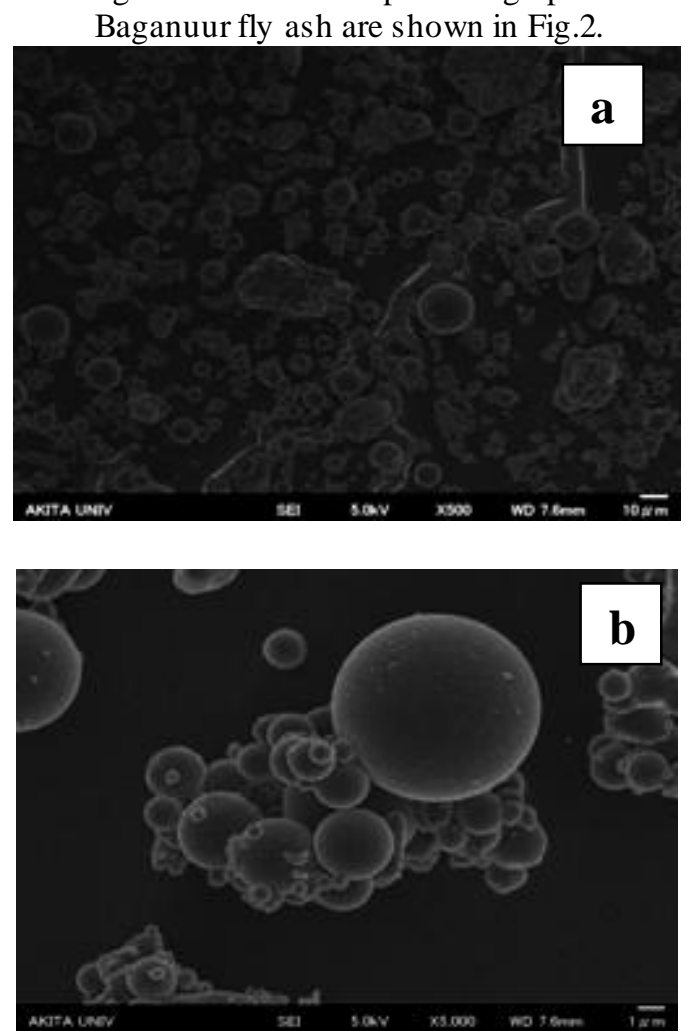

Fig.2. SEM micrographs of the Baganuur fly ash with (a) high, (b) low magnification 
SEM micrographs are in agreement with the particle size analysis result. The present fly ash consists of spherical and non-uniformed particles. Some of the spherical particles size is less than 1 micron. The fly ash characterisation results indicated that this fly ash can be used for the zeolite synthesis. From the reaction mixture the zeolititic compounds begin to crystallise (not shown here) at $100^{\circ} \mathrm{C}$ after $8 \mathrm{~h}$, but this temperature was not high enough for dissolving of the crystalline compounds of fly ash. After $8 \mathrm{~h}$ keeping at both 150 and $200^{\circ} \mathrm{C}$ temperatures most of the crystalline quartz were dissolved. In the reaction mixture were formed a several types of unidentified zeolitic compounds. However after $24 \mathrm{~h}$ treatment at both temperatures in either 2 and $4 \mathrm{M} \mathrm{NaOH}$ solutions was observed zeolite faujasite, Fig.3.

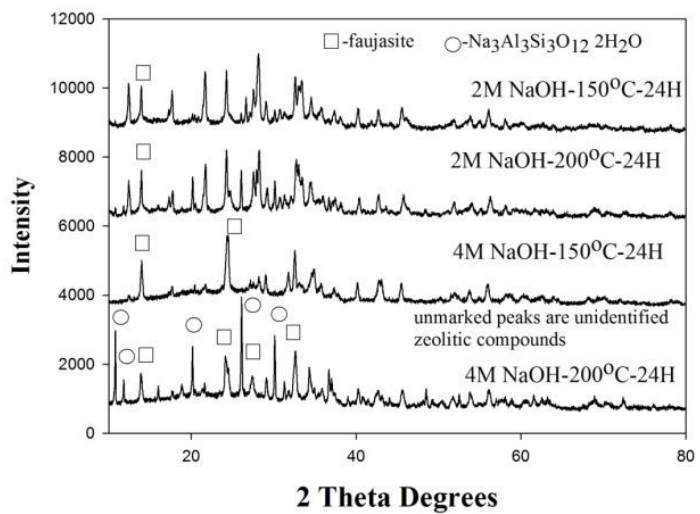

Fig.3. XRD patterns of the crystallised compounds formed after treatment of the reaction mixture in 2 and $4 \mathrm{M} \mathrm{NaOH}$ solutions at 150 and $200^{\circ} \mathrm{C}$ temperatures for $24 \mathrm{~h}$.

As XRD patterns indicate the crystallised zeolitic compounds were with $\mathrm{Al}$ rich composition which can be useful for adsorption or ion-exchange applications.

SEM micrographs of the powders obtained after treatment by 2 and $4 \mathrm{M} \mathrm{NaOH}$ at $200^{\circ} \mathrm{C}$ for $24 \mathrm{~h}$ are shown in Fig.4. According to Fig.3 both samples contain faujasite and by SEM elongated particle exists in both samples. Probably elongated rod like particle represents faujasite. Non-uniformed small particles appearing in the SEM micrographs may represent other zeolitic compounds that described in the XRD patterns of these samples.
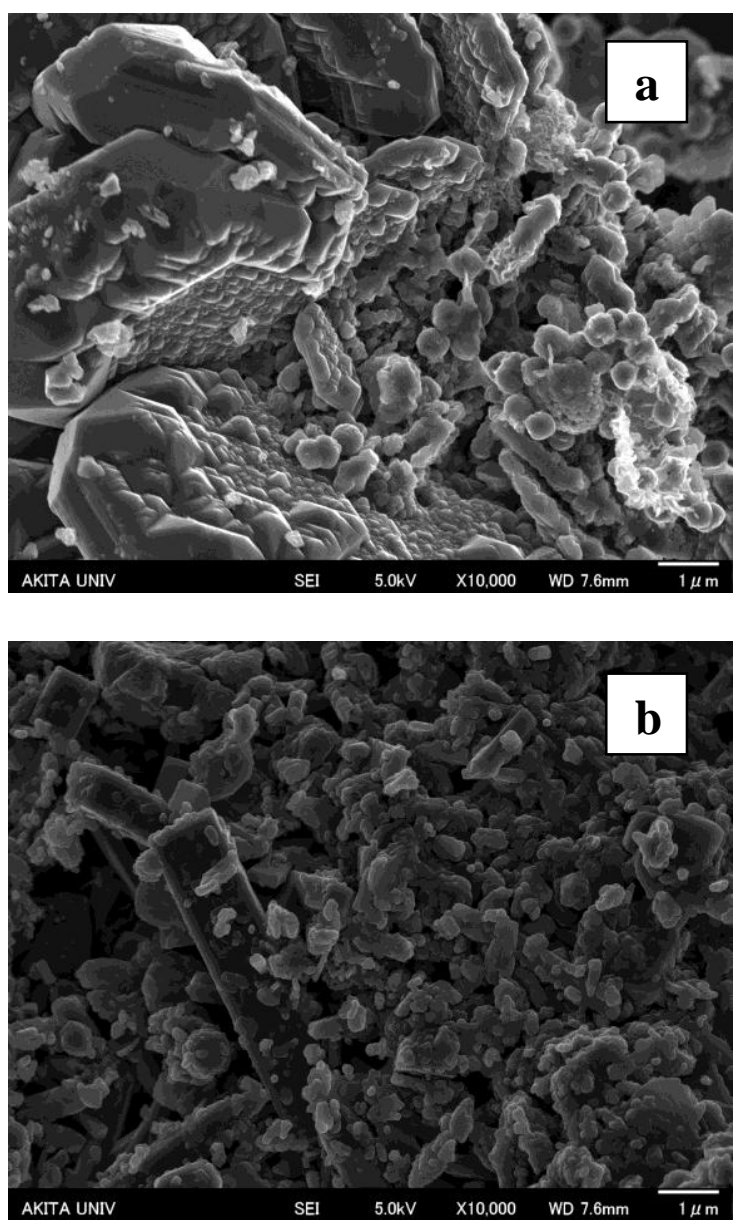

Fig.4. SEM micrographs of the powders treated at $200^{\circ} \mathrm{C}$ with $2 \mathrm{M} \mathrm{NaOH}$ (a) and $4 \mathrm{M}(\mathrm{NaOH})$ for $24 \mathrm{~h}$.

Ion-exchange and adsorption study of the prepared zeolitic compounds in a simulated tannery waste water is under way at presently.

\section{Conclusions}

Baganuur fly ash from 4th thermal power station of the Ulaanbaatar city represents mostly spherical particles with less than 50 micron size. This fly ash belongs to class $\mathrm{C}$ fly ash according to International classification. Baganuur fly ash can be used for the various types of zeolite syntheses under hydrothermal treatment at 150 and $200^{\circ} \mathrm{C}$ temperatures. There formed various types of zeolites including faujasite and $\mathrm{Na}_{3} \mathrm{Al}_{3} \mathrm{Si}_{3} \mathrm{O}_{12} \cdot 2 \mathrm{H}_{2} \mathrm{O}$.

\section{Acknowledgement}

J.T expresses his thanks to Minister of Education, Culture and Science of Mongolia for the award of Young Doctoral grant under which present research was carried out. 


\section{References}

1.M.Ahmaruzzman, A review on the utilisation of fly ash, Progress in Energy and Combustion Science, 36 (2010) 327-363

2. S.Wang, $\mathrm{H} . \mathrm{Wu}$, Environmental-benign utilisation of fly ash as low-cost adsorbents, Journal of Hazardous Materials B136 (2006) 482-501

3. V.K.Jha, M.Matsuda, M.Miyake, Resource recovery from coal ash waste: an overview study, Journal of the Ceramic Society of Japan 116, (2008) 167-175
4. X.Querol, J.C.Umania, F.Plana, A.Alastuey, A.Lopez-Soler, A.Medinaceli, A.Valero, M.J.Domingo, E.Garcia-Rojo, Synthesis of zeolites from fly ash in a Pilot plant scale. Examples of potential environmental applications. 1999 International ash utilization symposium, paper 12 .

5. W.Rickard, Thermal properties of fly ash geopolymers, Honours dissertation, Curtin University, Perth, Australia, 2007 